удк 342

DOI https://doi.org/10.32837/pyuv.v0i5(34).654

\author{
П. В. Вовк \\ orcid.org/0000-0002-8187-1849 \\ суддя, голова \\ Окружного адміністративного суду міста Києва
}

\title{
ПРОЦЕСУАЛЬНИЙ РЕЖИМ АДМІНІСТРАТИВНОГО СУДОЧИНСТВА: ДО ПИТАННЯ ВИЗНАЧЕННЯ СУТНОСТІ I ЗМІСТУ
}

Циклічність еволюційного розвитку процесуальної форми відправлення правосуддя, в тому числі у справах адміністративної юрисдикції, характеризується посиленням принципів диференціації та уніфікації у пошуках їхнього ідеального балансу. При цьому критичне домінування кожного із цих принципів є своєрідною точкою біфуркації для процесуальної форми, вимагає докорінного переосмислення ії̈ як на рівні цілісної системи, так і на рівні окремих елементів.

Після оновлення нормативного регулювання усіх процесуальних галузей загроза ситуації, коли специфіка адміністративного судочинства критично розмивається, а його особливості стають лише номінальними формальностями, стала цілком реальною. У такому разі існування адміністративного судочинства як самостійної процесуальної галузі вимагає виявлення і фіксації своїх ключових елементів у новій соціальноекономічній парадигмі.

Слід зауважити, що більшість досліджень процесуальної форми адміністративного судочинства здійснювалися в контексті лінійної моделі, що певним чином спрощує її зміст і не дозволяє розкрити ії унікальність повною мірою. У зв’язку з цим нагально постає потреба у розкритті елементів процесуальної форми адміністративного судочинства, що демонструють іï рівневість та багатовимірність. Одним із таких елементів є процесуальний режим.

Питання процесуального режиму адміністративного судочинства у вітчизняних джерелах майже не висвітлюється. Надзвичайно мало наукових доробок із цього питання і на рівні загальнотеоретичної юриспруденції. Так, визнання процесуального режиму елементом процесуальної форми слід визнати здобутком В.М. Горшеньова. Водночас рівень дослідженості феномену процесуального режиму і досі відповідає лише констатації його існування без подальшої деталізації та виявлення галузевої специфіки.

Для адміністративного судочинства актуальність аналізу категорії «процесуальний режим» пов'язана також із їі нормативною фіксацією в КАС України та «зростанням популярності»у правозастосуванні у зв'язку з дією обмежувальних карантинних заходів. Таким чином, звернення до питання правової природи, сутності та змісту категорії «процесуальний режим» є важливим не лише для формування оновленого концепту процесуальної форми адміністративного судочинства, але і має безпосереднє значення для удосконалення сучасної практичної діяльності адміністративних судів. Кількість публікацій, присвячених проблемі процесуальних режимів, $€$ недостатньою для того, щоб можна було робити однозначні висновки про домінуючі тенденції визначення правової природи цієї категорії. У небагатьох загальнотеоретичних дослідженнях сформульовано декілька взаємовиключних підходів до бачення його взаємозв'язку із процесуальною формою: від визнання їх самостійності (В.П. Беляєв) [1] до змістовного ототожнення (О.Г. Лук'янова) [3]. Поширеним є сприйняття процесуального режиму і як елементу процесуальної форми (В.М.Горшеньов[8], О.С. Родіонов[4]тощо). У галузевих дослідженнях найбільшу увагу питанням режиму приділено фахівцями у сфері кримінального процесу, водночас всі вони зосереджені на з'ясуванні особливостей процесуального режиму окремих процедур кримінального судочинства (I.I. Шепітько, О.В. Лазукова, Н.В. Шульга). Особливо слід відзначити комплексну монографічну працю Д.О. Фурсова [9], який досліджує цю категорію у сфері арбітражного судочинства, а також дисертаційне дослідження Я.Я. Мельника, значна частина якого торкається проблематики визначення особливостей процесуального режиму цивільного судочинства [4]. На жаль, адміністративне судочинство і досі залишається сферою, у якій питання процесуального режиму не піддано науковому осмисленню, попри те, що їі особливості не можуть не позначитися на змістовному наповненні даної категорії.

Метою статті є з'ясування сутності та змісту процесуального режиму та визначення його особливостей в адміністративному судочинстві. Досягнення зазначеної мети можливе за умови визначення характеру зв'язку між процесуальною формою і процесуальним режимом адміністративного судочинства, встановлення складників процесуального режиму та їх ретельного аналізу 3 урахуванням сучасних змін правового регулювання адміністративного судочинства в Україні. 
Виклад основного матеріалу. Як було зазначено вище, правова природа процесуального режиму залишається й досі не визначеною. Узагальнення наявних підходів дає змогу сформулювати три основні бачення сутності процесуального режиму. По-перше, тривалий час термін «процесуальний режим» використовувався фахівцями як синонім поняття "процесуальна форма», чиє визначення також було настільки розмитим, що сприймалося майже ідентично із провадженням чи судочинством як таким. Попри те, що прямо на такий збіг термінології не вказувалося, але трактування усіх наведених процесуальних категорій зводилося до їх визначення як сукупності, алгоритму або послідовності процесуальних дій. При цьому у характеристиці процесуального режиму робився акцент на «атмосферності» цього явища [1, с. 67-68].

На противагу цьому, С.Н. Назаров розглядає процесуальний режим як процесуальне регулювання юридичної діяльності і таким чином пропонує розглядати процесуальну форму як предмет такого регулювання [5, с. $35-36]$. Водночас розгляд процесуального режиму лише у площині правового регулювання необгрунтовано звужує зазначену категорію.

Дослідження представників галузевих процесуальних наук вивели науковий пошук сутності та змісту процесуального режиму на необхідність з'ясування конкретних процесуальних засобів, які дозволяють реалізуватися меті правового регулювання судочинства і розкритися специфіці процесуальної форми його різновидів. У зв'язку з цим доречно навести висловлювання Д.О. Фурсова, який звертає увагу на те, що процесуальний режим визначає реальні можливості арбітражного суду ... повно і всебічно встановити юридичні факти по даній справі, правильно застосувати норми матеріального та процесуального права, вжити заходів до забезпечення виконання судового рішення, визначає ступінь відповідності можливостей арбітражного суду тим завданням, які покладені на нього законом $[9$, с. 146]. Таким чином, процесуальний режим можна розглядати як елемент процесуальної форми, який надає їй рис об'ємного явища, дозволяє відійти від лінійної конструкції, оскільки дозволяє інтегрувати у процесуальний рух справи численні процесуальні інститути, які «вибиваються» із суворої послідовності процесуальних дій. Процесуальний режим у цьому разі визначає специфіку ситуації, в межах якої протікає судовий процес, забезпечує оптимальні умови для діяльності усіх його суб'єктів, а також визначає унікальні для цієї ситуації способи здійснення та гарантії забезпечення процесуальної діяльності [7, с. 48]. Так, для адміністративного судочинства роль процесуального режиму можна проілюструвати на прикладі процедури примусового доставляння свідків або провадження із виконання судового наказу.
Відмінність підходів щодо розуміння сутності категорії «процесуальний режим» зумовлюється

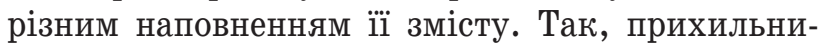
ки «атмосферного» підходу до визначення процесуального режиму зараховують до його змісту максимально широкий набір елементів, в тому числі і неправового характеру, такі як норми етики, естетики, звичаї, тобто усю сукупність соціальних факторів, які формують відповідну «атмосферу» правозастосування [8, с. 152].

Якщо проаналізувати підходи вчених, що є прихильниками «нормативістського» бачення сутності категорії «процесуальний режим», можна виокремити такі його елементи. По-перше, нормативно визначена процесуальна ситуація або обстановка. Це сукупність характеристик справи, які визначаються специфікою процесуальних правовідносин, що виникли. При цьому слід зауважити, що йдеться не про конкретизовані індивідуальні справи, а про їхні типи. Так, наприклад, в адміністративному судочинстві процесуальними ситуаціями можна вважати типову, термінову, складну, малозначну, зразкову та звичайну справи тощо.

По-друге, процесуальні засоби здійснення адміністративного судочинства щодо певної нормативно визначеної ситуації. В цьому разі йдеться про правовий інструментарій, який використовується для забезпечення інтересів суб'єктів адміністративного судочинства. Частіше за все цей інструментарій відбивається у конкретних повноваженнях адміністративного суду, правах і обов'язках учасників процесу. Слід підтримати позицію А.В. Рибіна, який відзначав, що виконуючи функції з юридичного забезпечення втілення ідей процесуальних принципів, процесуальні засоби відіграють самостійну роль в організації юридичного процесу шляхом визначення меж процесуальної діяльності і закріплення параметрів правомірної поведінки в юридичному процесі, демонструють особливу спрямованість процесуально-правового регулювання і в кінцевому підсумку є визначальним елементом процесуального режиму [7, с. 49].

Слід звернути увагу, що, на наш погляд, до процесуальних засобів слід зараховувати і гарантії процесуальної діяльності адміністративного суду та учасників процесу, хоча окремими дослідниками обстоюється самостійність такого елементу процесуального режиму [7, с. 44]. Як уявляється, цілком прийнятним $є$ визначення процесуальних гарантій як установлених законом норм, що забезпечують здійснення завдань правосуддя наданням всім учасникам процесуальних прав та покладанням на державні органи обов'язків із забезпечення реалізації цих прав [10, с. 11]. Таким чином, процесуальні гарантії, хоча і виконують специфічну функцію, але цілком охоплюються поняттям процесуальних засобів. 
По-третє, процесуально-правове регулювання. Цей елемент процесуального режиму визначає специфіку його встановлення, робить його прогнозованим і зрозумілим для учасників процесу. Характеризуючи сучасне правове регулювання процесуального режиму, слід звернути увагу на те, що в ньому посилюється роль міжнародних стандартів відправлення адміністративного судочинства, а також рішень Європейського суду з прав людини.

Окрему увагу слід звернути на принципи здійснення процесуальної діяльності. Цей елемент, на відміну від раніше перелічених, не викликає жодних заперечень усіма дослідниками процесуального режиму та одностайно визнається його складником. Як зазначає В.М. Горшенев, особливістю принципів процесуальної діяльності є те, що в їх змісті закріплюються програмно-прогнозучі основи, в результаті чого стає можливим змоделювати характер юридичної процесуальної діяльності в майбутньому [8, с. 154]. Як елемент процесуального режиму, принципи процесуальної діяльності формують $\dddot{1}$ «фон», структурують усі інші вищеперелічені елементи.

Важливо також відзначити, що наведені елементи процесуального режиму є системними і мають оцінюватися у сукупності. Виокремлення певної категорії справ передбачає наявність чіткого, узгодженого процесуально-правового регулювання і наявності достатніх процесуальних засобів, які забезпечать повноцінну реалізацію принципів адміністративного судочинства і досягнення його мети. Так, наприклад, оцінка елементів процесуального режиму розгляду і вирішення типових справ в адміністративному судочинстві дозволяе зробити висновок про недосконалість їх процесуально-правового регулювання та недостатність процесуальних засобів, здатних задовольнити інтереси учасників адміністративного процесу у швидкому і об'єктивному розгляді таких справ.

Зважаючи на те, що процесуальна форма розглядається нами як складна багаторівнева конструкція, слід відзначити, що і процесуальний режим, як її елемент, присутній на кожному із рівнів. Відтак можна говорити про загально-процесуальний, диференційований та стадійний piвень процесуального режиму адміністративного судочинства. Як уявляється, на загально-процесуальному рівні процесуальний режим має прояв у наявності системи процесуальних засобів реалізації принципів адміністративного судочинства, конкретних повноважень суду, прав і обов'язків учасників процесу, які дозволяють використовувати ці принципи в усіх видах проваджень і на кожні стадії процесу. Так, наприклад, законодавець зобов'язує суд вживати заходи, необхідні для з'ясування всіх обставин у справі, у тому числі щодо виявлення та витребування доказів з власної ініціативи, надає можливість виходу за межі позовних вимог (ст. 4 КАС України) [2]. Ми бачимо усі ознаки наявності специфічного процесуального режиму: 1) формування особливої ситуації - потреби ефективного захисту прав, свобод, інтересів людини і громадянина або інших суб'єктів у сфері публічно-правових відносин від порушень з боку суб'єктів владних повноважень в умовах, коли у приватної особи недостатньо власних ресурсів повноцінно захищати свої інтереси в суді; 2) нормативне закріплення конкретних засобів, які дозволяють суду здійснити такий захист в межах загального або скороченого позовного провадження; 3) встановлення системи гарантій реалізації права особи на судовий захист у зазначених умовах.

На диференційованому рівні в адміністративному судочинстві формуються декілька процесуальних режимів, які дозволяють максимально ефективно досягти завдань адміністративного процесу під час розгляду справ в порядку загального позовного провадження, спрощеного позовного провадження або особливого (непозовного провадження). Кожне із зазначених проваджень залежно від специфіки конкретної ситуації може проходити із використанням можливостей, що законодавчо передбачені для електронного провадження, письмового чи очного провадження. Процесуальний режим електронного, письмового чи очного провадження повністю охоплює усі стадії окремого виду провадження в межах відповідного процесуального циклу: від його відкриття до виконання. Так, наприклад, щодо справи, яка розглядається в суді першої інстанції в порядку загального позовного провадження, використано режим очного провадження. На наступному процесуальному циклі (в апеляційному провадженні) процесуальний режим загального позовного провадження може бути змінено на письмове провадження і так далі.

Слід також врахувати, що процесуальний режим може «капсулювати» не лише цілісні процесуальні форми адміністративного судочинства, але і його окремі стадії. Так, наприклад, режим «відеоконференція» властивий для стадії розгляду справи по суті і може бути цілком самодостатнім поза межами електронного провадження, забезпечувати ефективне досягнення цілей адміністративного судочинства загалом і цілей названої стадії зокрема, наприклад під час використання процесуальної форми очного чи письмового провадження.

Варто окремо зупинити увагу на процесуальному режимі закритого провадження. Згідно зі ст. 10 KАС України розгляд справи у закритому судовому засіданні проводиться у випадках, коли відкритий судовий розгляд може мати наслідком розголошення таємної чи іншої інформації, 
що охороняється законом, необхідності захисту особистого та сімейного життя людини, а також в інших випадках, визначених законом [2]. Такий режим вносить певні корективи у загально-процесуальний рівень адміністративного судочинства, оскільки впливає на умови реалізації принципів гласності судового процесу і відкритості інформації щодо справи. Попри те, що найбільш повно цей режим має прояв на стадії розгляду справи по суті, його не варто розглядати як прояв стадійного рівня процесуальних режимів, адже окремі його елементи є присутніми і на стадії підготовчого провадження, і на стадії виконання судового рішення. Відтак, попри низку відмінностей, на наш погляд, режим закритого засідання найбільш доречно розглядати як диференційований процесуальний режим адміністративного судочинства.

Висновки. Процесуальний режим слід розглядати як елемент процесуальної форми адміністративного судочинства, який формує умови іiї найбільш ефективної реалізації. Він є забезпечувальним механізмом досягнення мети адміністративного судочинства загалом, а також його окремих проваджень і стадій. До елементів процесуального режиму слід зарахувати: принципи процесуальної діяльності, процесуальну обстановку (тип адміністративної справи), процесуально-правове регулювання та процесуальні засоби. В адміністративному судочинстві слід виокремлювати загально-процесуальний, диференційований та стадійний рівень процесуального режиму. Рівневість процесуального режиму дозволяє більш детально проаналізувати ефективність його нормативного забезпечення, достатність гарантій і процесуальних засобів, що його складають.

\section{Jimepamypa}

1. Беляев В.П., Беляева Г.С., Рубченко С.О. Процессуально-правовой режим юридической деятельности: монография. Курск. 2011. 166 с. URL: http://l awlibrary.ru/izdanie2209722.html (дата звернення: 23.10 .2020 р.).

2. Кодекс адміністративного судочинства України: Закон України від 6.07.2005. № 2747-IV. URL: https://zakon.rada.gov.ua/laws/show/2747. 15\#Text (дата звернення: 23.10.2020р.).

3. Лукьянова Е.Г. Теория процессуального права. Москва : Норма, 2004. 240 с.

4. Мельник Я.Я. Безпека цивільного процесу: теоретико-правове дослідження: автореферат дис. ... д-ра юрид. наук. Київ, 2019. 40 c. URL: http://instzak.rada. gov.ua/uploads/documents/31780.pdf (дата звернення: 23.10.2020 p.).

5. Назаров С.Н. Понятие процессуально-правового режима и его видов. Вестник Волжского универ ситета им. В.Н. Татищева. 2007. Вып. 64. С. 36-42. URL: https://www.elibrary.ru/item.asp?id=17885989 (дата звернення: 23.10.2020 p.).

6. Родионов О.С. Механизм установления правовых режимов. Саратов. 2001. 236 с.
URL: https://www.dissercat.com/content/mekhanizmustanovleniya-pravovykh-rezhimov (дата звернення: 23.10.2020 p.).

7. Рыбин А.В. Процессуальный режим: понятие и структура. Вопросы эконолики и права. 2011. № 9. C. 42-48. URL: https://law-journal.ru/files/pdf/ 201109/201109_47.pdf (дата звернення: 23.10.2020 р.).

8. Теория юридического процесса / под общей ред. проф. В.М. Горшенева. Харьков, 1985. 193 с.

9. Фурсов Д.А. Процессуальный режим деятельности арбитражного суда первой инстанции: монография. Москва, 1997. 320 с.

10. Молдован В.В., Кацавець Р.С. Кримінальний процес України: навчальний посібник. Київ, 2006. 297.

\section{Анотація}

Вовк П. В. Процесуальний режим адміністративного судочинства: до питання визначення сутності і змісту. - Стаття.

У статті з'ясовано сутність та зміст процесуального режиму та визначено його особливості в адміністративному судочинстві. Доведено, що процесуальний режим $\epsilon$ забезпечувальним механізмом досягнення мети адміністративного судочинства загалом, а також його окремих проваджень і стадій.

Встановлено, що процесуальний режим є елементом процесуальної форми, який надає їй рис об'ємного явища, дозволяє відійти від лінійної конструкції, оскільки дозволяє інтегрувати у процесуальний рух справи численні процесуальні інститути, які «вибиваються» із суворої послідовності процесуальних дій. Процесуальний режим у цьому разі визначає специфіку ситуації, в межах якої протікає судовий процес, забезпечує оптимальні умови для діяльності усіх його суб'єктів, а також визначає унікальні для цієї ситуації способи здійснення та гарантії забезпечення процесуальної діяльності.

Виокремлено такі елементи процесуального режиму, як: нормативно визначена процесуальна ситуація або обстановка; процесуальні засоби здійснення адміністративного судочинства щодо певної нормативно визначеної ситуації; процесуально-правове регулювання; принципи здійснення процесуальної діяльності. Наведені елементи процесуального режиму є системними і мають оцінюватися у сукупності. Виокремлення певної категорії справ передбачає наявність чіткого, узгодженого процесуально-правового регулювання і наявності достатніх процесуальних засобів, які забезпечать повноцінну реалізацію принципів адміністративного судочинства і досягнення його мети.

Встановлено, що на диференційованому рівні в адміністративному судочинстві формуються декілька процесуальних режимів, які дозволяють максимально ефективно досягти завдань адміністративного процесу під час розгляду справ у порядку загального позовного провадження, спрощеного позовного провадження або особливого (непозовного провадження). Кожне із зазначених проваджень залежно від специфіки конкретної ситуації може проходити із використанням можливостей, що законодавчо передбачені для електронного провадження, письмового чи очного провадження. Процесуальний режим електронного, письмового чи очного провадження повністю охоплює усі стадії окремого виду провадження в межах відповідного процесуального циклу: від його відкриття до виконання.

Ключові слова: процесуальний режим, адміністративне судочинство, забезпечувальний механізм, змістовний елемент, вид провадження. 


\section{Summary}

Vovk $P . V$. Procedural regime of administrative proceedings: to the question of determining the essence and content. - Article.

The article clarifies the essence and content of the procedural regime and identifies its features in administrative proceedings. It is proved that the procedural regime is a providing mechanism for achieving the goal of administrative proceedings as a whole, as well as its proceedings and stages.

It is established that the procedural regime is an element of the procedural form, which gives it the features of a three-dimensional phenomenon, allows to move away from the linear structure, as it allows to integrate into the procedural movement of numerous procedural institutions. The procedural regime in this case determines the specifics of the situation in which the trial takes place, provides optimal conditions for the activities of all its subjects, as well as determines the unique for this situation ways of implementation and guarantees of procedural activities.

The following elements of the procedural regime are singled out as: normatively defined procedural situation; procedural means of administrative proceedings in relation to a certain normatively defined situation; procedural and legal regulation; principles of procedural activity. These elements of the procedural regime are systemic and should be assessed together. The separation of a certain category of cases presupposes the existence of clear, coherent procedural and legal regulation and the availability of sufficient procedural means that will ensure the full implementation of the principles of administrative proceedings and the achievement of its purpose.

It is established that at the differentiated level in administrative proceedings several procedural regimes are formed, which allow to achieve the tasks of the administrative process as effectively as possible when considering cases in the order of general claim proceedings, simplified claim proceedings or special (non-claim proceedings). Depending on the specifics of the specific situation, each of these proceedings may take place using the opportunities provided by law for electronic, written or in-person proceedings. The procedural regime of electronic, written or face-to-face proceedings fully covers all stages of a particular type of proceedings within the relevant procedural cycle: from its opening to execution.

Key words: procedural regime, administrative proceedings, security mechanism, substantive element, type of proceedings. 